\title{
Effects of cadmium on gas exchange and phytohormone contents in citrus
}

\author{
M.F. LÓPEZ-CLIMENT, V. ARBONA, R.M. PÉREZ-CLEMENTE and A. GÓMEZ-CADENAS* \\ Departamento de Ciencias Agrarias y del Medio Natural, Universidad Jaume I, \\ Campus Riu Sec, E-12071 Castellón, Spain.
}

\begin{abstract}
The effect of increased $\mathrm{Cd}^{2+}$ concentrations in the watering solution on citrus physiology was studied by using two citrus genotypes, Cleopatra mandarin and Carrizo citrange. Cadmium content in roots and leaves was tested together with measurements of leaf damage, gas exchange parameters, and hormonal contents. Citrus roots efficiently retained $\mathrm{Cd}^{2+}$ avoiding its translocation to the shoots and Cleopatra mandarin translocated less $\mathrm{Cd}^{2+}$ than Carrizo. With increasing $\mathrm{Cd}^{2+}$ concentration all gas exchange parameters were decreased more in Carrizo than in Cleopatra mandarin. Cd-induced increases in abscisic acid and salicylic acid contents were observed in leaves but not in roots of both genotypes.
\end{abstract}

Additional key words: abscisic acid, net photosynthetic rate, jasmonic acid, salicylic acid, stomatal conductance, transpiration rate.

Cadmium ions are easily absorbed by plant roots. In some species $\mathrm{Cd}^{2+}$ remains in roots (Rascio et al. 2008, Jiang et al. 2009) whereas in other species, such as tobacco, $\mathrm{Cd}^{2+}$ is translocated to the leaves. Nevertheless, the $\mathrm{Cd}^{2+}$ content is usually much higher in roots than in leaves (Wagner 1993). Grafting experiments have been performed in Nicotiana species indicating that the responsible mechanisms for limited translocation are located in the roots (Lugon-Moulin et al. 2004). In the case of citrus, scarce information can be found on the ability of plants to translocate $\mathrm{Cd}^{2+}$ from roots to aerial parts.

The symptoms of $\mathrm{Cd}^{2+}$ toxicity are well documented in several herbaceous species (Di Toppi and Gabbrielli 1999, Jiang et al. 2009). Visible effects of exposure to the high metal doses are growth inhibition and leaf chlorosis. The photosynthetic apparatus, the water balance and the stomatal opening are also seriously disturbed (Rascio et al. 2008). Oxidative stress has often been discussed as a primary effect of $\mathrm{Cd}^{2+}$ exposure (Markovska et al. 2009, Rodriguez-Serrano et al. 2009). Recently, it has been shown that microtubular cytoskeleton is one of the targets of Cd toxicity in root tip cells (Xu et al. 2009).
Among responses to $\mathrm{Cd}^{2+}$, synthesis of phytochelatins has been extensively studied (Ben Ammar et al. 2008) and constitutes a specific plant response to metal toxicity. Another group of well-known responses is the upregulation of stress proteins (Schutzendubel et al. 2001) or the accumulation of proline (Schat et al. 1997). Only a few studies have indirectly implicated the stress hormones jasmonate and ethylene in the transcriptional control of pathogen-related and heat shock proteins under $\mathrm{Cd}^{2+}$ excess, probably to protect cells against damage induced by $\mathrm{Cd}^{2+}$ treatment (Rodriguez-Serrano et al. 2009).

Despite the lack of studies on the effect of $\mathrm{Cd}^{2+}$ on citrus physiology, the response of this crop to other environmental stresses has been extensively studied. It is known that Cleopatra mandarin, a commercial rootstock, is able to restrict $\mathrm{Cl}^{-}$transport to the aerial part whereas leaves of Carrizo citrange (another widely used rootstock) becomes rapidly intoxicated in the presence of high concentrations of $\mathrm{NaCl}$ (López-Climent et al. 2008). In response to different environmental stresses a crucial role for abscisic acid (ABA) and jasmonic acid (JA) has been suggested (Arbona and Gómez-Cadenas 2008).

Received 7 August 2009, accepted 26 April 2010.

Abbreviations: ABA - abscisic acid; CC - Carrizo citrange; CM - Cleopatra mandarin; JA - jasmonic acid; SA - salicylic acid. Acknowledgements:This work was supported by the Spanish Ministerio de Ciencia e Innovación and the Generalitat Valenciana through grants No. AGL2007-65437-C04-03/AGR and ACOMP/2009/091, respectively. Hormone determinations were performed in the central facilities (Servei Central d'Instrumentació Científica, SCIC) of Universitat Jaume I. M.F. López-Climent was recipient of a fellowship from Universitat Jaume I.

* Corresponding authors; fax: (+34) 964728216, e-mail: aurelio.gomez@uji.es 
The objective of this work was to elucidate $\mathrm{Cd}$ translocation from the roots to the leaves in citrus and changes in phytohormones in response to Cd stress.

One-year-old seedlings of Carrizo citrange (CC; Poncirus trifoliata L. Raf. $\times$ Citrus sinensis L. Osb.) and Cleopatra mandarin (CM; Citrus reshni Hort. ex. Tan.) were transplanted to $2 \mathrm{dm}^{3}$ plastic pots with Perlite as a substrate. Plants were allowed to acclimate for one month in a greenhouse with natural photoperiod, $25 / 18{ }^{\circ} \mathrm{C}$ day/night temperature and $60-85 \%$ relative humidity. During this period, plants were watered three times a week with $0.5 \mathrm{dm}^{3}$ of a half-strength Hoagland solution (López-Climent et al. 2008). Two different experiments were performed. 1) Three groups of 14 plants per genotype were set as control plants, plants treated with $1.5 \mathrm{mM} \mathrm{Cd}^{2+}$ and plants treated with $3 \mathrm{mM} \mathrm{Cd}^{2+}(\mathrm{Cd}-$ treated plants were watered three times a week with the nutrient solution mentioned above plus $\mathrm{Cd}\left(\mathrm{NO}_{3}\right)_{2}$ to achieve the desired $\mathrm{Cd}^{2+}$ concentrations and control plants were identically watered but $\mathrm{Cd}\left(\mathrm{NO}_{3}\right)_{2}$ was omitted). 2) Sixty nine seedlings for each genotype were separated in three different groups. One group was set as a control and the other two were treated with $\mathrm{Cd}\left(\mathrm{NO}_{3}\right)_{2}$ $\left(30 \mu \mathrm{M} \mathrm{Cd}^{2+}\right.$ and $\left.150 \mu \mathrm{M} \mathrm{Cd}^{2+}\right)$. Plants were watered as in the first experiment.

In response to $\mathrm{Cd}$ treatment, plants showed symptoms of leaf damage such as vein yellowing and curling. Plants showing a percentage of damaged leaves equal or above $50 \%$ were considered cadmium "affected". Leaf gas exchange parameters were measured with a LCpro+ portable infrared gas analyzer (ADC Bioscientific, Hoddesdon, UK) under ambient $\mathrm{CO}_{2}$ and humidity (López-Climent et al. 2008). After instrument stabilization, measurements were taken on 12 mature leaves. For analyses, frozen plant material was ground to a fine powder using a pre-chilled mortar and pestle. Part of that tissue was stored at $-80^{\circ} \mathrm{C}$ while other was immediately lyophilized. Cadmium content was determined using $1 \mathrm{~g}$ of plant fresh mass that was digested with $10 \mathrm{~cm}^{3}$ of $35 \%$ nitric acid (Panreac S.A., Barcelona, Spain) for $3 \mathrm{~h}$ in an oven at $120^{\circ} \mathrm{C}$. After that, extracts were filtered and $\mathrm{Cd}^{+2}$ content was measured by inductively coupled plasma mass spectrometry (ICP-MS 7500cx Agilent, Santa Clara, CA, USA). Plant hormones were assayed according to Arbona and Gómez-Cadenas (2008) by using liquid chromatography linked to a mass spectrometer. All data presented are means \pm standard errors. Statistical analyses were performed using StatGraphics Plus (V. 2.1.) for Windows (Statistical Graphics Corp., Warrenton, VA, USA). Differences between treatments were compared by using the least significant difference (LSD) test $(P \leq 0.05)$.

In preliminary experiments, citrus plants showed a remarkable tolerance to $\mathrm{Cd}$. Therefore, plants watered with a solution containing $30 \mu \mathrm{M} \mathrm{Cd}{ }^{2+}$ did not show observable leaf damage symptoms for more than three months. In plants treated with 150 or $300 \mu \mathrm{M} \mathrm{Cd}^{2+}$, first symptoms were observable after $50 \mathrm{~d}$ and no plant death occurred throughout a 205-d experimental period. Higher metal concentration were more toxic for $\mathrm{CC}$ and, in a few days, all plants watered with 1.5 or $3 \mathrm{mM} \mathrm{Cd}^{2+}$ were affected (Table 1).

To test the ability of citrus genotypes to exclude $\mathrm{Cd}$ from the aerial part, $\mathrm{CC}$ and $\mathrm{CM}$ plants were watered for one month with a solution containing toxic concentrations of $\mathrm{Cd}$. Very high endogenous levels of $\mathrm{Cd}^{2+}$ were detected in roots of both genotypes when the watering solution was supplemented with either $1.5 \mathrm{mM}$ or $3 \mathrm{mM} \mathrm{Cd}^{2+}$ (Table 2). Metal buildup in roots was fast and progressive in plants under both treatments and virtually no differences in this parameter were observed between $\mathrm{CC}$ and CM. $\mathrm{Cd}^{2+}$ concentration in leaves was markedly lower than in roots in both genotypes (Table 2). Furthermore, $\mathrm{Cd}$ accumulation in leaves was distinct between the two genotypes, being $\mathrm{CM}$ able to exclude even more $\mathrm{Cd}$ from the aerial part than $\mathrm{CC}$.

Leaf $\mathrm{Cd}$ concentration was correlated with damage. Although both genotypes suffered from important damage under the high doses of $\mathrm{Cd}, \mathrm{CM}$ was less affected (Table 1). Leaf damage was also correlated with the inhibition of net photosynthetic rate. Although reduction in net photosynthetic rate was observed in both genotypes, it was higher in CC. Similar trends were observed when the transpiration rate and the stomatal conductance were studied under these high doses of $\mathrm{Cd}$ (Table 1).

Table 1. Effect of Cd treatments on leaf damage (means \pm SE, $n=14)$ and gas exchange parameters $(n=12)$ in citrus plants CC and CM. Asterisks denote significant differences at $P \leq 0.05$ between control and treated plants on each date.

\begin{tabular}{|c|c|c|c|c|c|c|c|c|c|}
\hline \multirow[t]{2}{*}{ Plant } & \multirow[t]{2}{*}{$\begin{array}{l}\mathrm{Cd} \\
{[\mathrm{mM}]}\end{array}$} & \multicolumn{2}{|c|}{$\begin{array}{l}\text { Affected plants } \\
{[\%]}\end{array}$} & \multicolumn{2}{|c|}{$\begin{array}{l}\text { Net photosyntetic rate } \\
{\left[\mu \mathrm{mol} \mathrm{m} \mathrm{m}^{-2} \mathrm{~s}^{-1}\right.}\end{array}$} & \multicolumn{2}{|c|}{$\begin{array}{l}\text { Transpiration rate } \\
{\left[\mathrm{mol} \mathrm{m}^{-2} \mathrm{~s}^{-1}\right]}\end{array}$} & \multicolumn{2}{|c|}{$\begin{array}{l}\text { Stomatal conductance } \\
{\left[\mathrm{mmol} \mathrm{m}^{-2} \mathrm{~s}^{-1}\right]}\end{array}$} \\
\hline & & $10 \mathrm{~d}$ & $25 \mathrm{~d}$ & $10 \mathrm{~d}$ & $25 \mathrm{~d}$ & $10 \mathrm{~d}$ & $25 \mathrm{~d}$ & $10 \mathrm{~d}$ & $25 \mathrm{~d}$ \\
\hline \multirow[t]{3}{*}{$\mathrm{CC}$} & 0 & 0 & 0 & $5.71 \pm 0.32$ & $7.26 \pm 0.27$ & $1.29 \pm 0.06$ & $1.49 \pm 0.04$ & $48.05 \pm 2.86$ & $66.66 \pm 2.44$ \\
\hline & 1.5 & $72 \pm 1 *$ & $85 \pm 2 *$ & $3.52 \pm 0.35^{*}$ & $0.67 \pm 0.22 *$ & $0.97 \pm 0.06 *$ & $0.39 \pm 0.03 *$ & $31.38 \pm 2.07 *$ & $16.94 \pm 1.63^{*}$ \\
\hline & 3.0 & $88 \pm 2 *$ & $100 \pm 3^{*}$ & $1.59 \pm 0.18^{*}$ & $0.42 \pm 0.11^{*}$ & $0.59 \pm 0.03 *$ & $0.16 \pm 0.01^{*}$ & $16.66 \pm 1.11^{*}$ & $10.83 \pm 2.33^{*}$ \\
\hline \multirow[t]{3}{*}{$\mathrm{CM}$} & 0 & 0 & 0 & $2.65 \pm 0.14$ & $2.43 \pm 0.13$ & $0.66 \pm 0.12$ & $0.67 \pm 0.03$ & $24.44 \pm 0.83$ & $25.00 \pm 1.16$ \\
\hline & 1.5 & $16 \pm 2 *$ & $60 \pm 3 *$ & $2.71 \pm 0.15$ & $0.35 \pm 0.11^{*}$ & $0.73 \pm 0.03$ & $0.27 \pm 0.02 *$ & $28.33 \pm 1.93^{*}$ & $11.10 \pm 0.10^{*}$ \\
\hline & 3.0 & $56 \pm 1 *$ & $83 \pm 2 *$ & $1.80 \pm 0.13^{*}$ & $0.10 \pm 0.02 *$ & $0.50 \pm 0.03 *$ & $0.23 \pm 0.01 *$ & $18.33 \pm 1.16^{*}$ & $10.05 \pm 0.06^{*}$ \\
\hline
\end{tabular}

Table 2. Effect of Cd treatments on endogenous cadmium and hormone contents in roots (R) and leaves (L) of citrus plants CC and 
$\mathrm{CM}$ (means $\pm \mathrm{SE}, n=3$, asterisks denote significant differences at $P \leq 0.05$ between control and treated plants on each date).

\begin{tabular}{|c|c|c|c|c|c|c|c|c|c|}
\hline \multirow[t]{2}{*}{ Plant } & \multirow[t]{2}{*}{$\begin{array}{l}\mathrm{Cd} \\
{[\mathrm{mM}]}\end{array}$} & \multicolumn{2}{|l|}{$\begin{array}{l}\mathrm{Cd}^{2+} \\
{\left[\mu \mathrm{g} \mathrm{g}^{-1}(\text { F.W. })\right]}\end{array}$} & \multicolumn{2}{|c|}{$\begin{array}{l}\text { JA } \\
{\left[\mathrm{ng} \mathrm{g}^{-1}(\text { F.W. })\right]}\end{array}$} & \multicolumn{2}{|c|}{$\begin{array}{l}\mathrm{ABA} \\
{\left[\operatorname{ng~g}^{-1}(\mathrm{~F} . \mathrm{W} .)\right]}\end{array}$} & \multicolumn{2}{|c|}{$\begin{array}{l}\text { SA } \\
{\left[\operatorname{ng~g}^{-1}(\text { F.W. })\right]}\end{array}$} \\
\hline & & $10 \mathrm{~d}$ & $25 \mathrm{~d}$ & $10 \mathrm{~d}$ & $25 \mathrm{~d}$ & $10 \mathrm{~d}$ & $25 \mathrm{~d}$ & $10 \mathrm{~d}$ & $25 \mathrm{~d}$ \\
\hline \multirow[t]{3}{*}{ CC-R } & 0 & $0.6 \pm 0.1$ & $0.7 \pm 0.1$ & $113.9 \pm 7.1$ & $153.9 \pm 2.8$ & 11.8 & 4.4 & 3.0 & 55.4 \\
\hline & 1.5 & $690 \pm 26 *$ & $6610 \pm 259 *$ & $43.4 \pm 0.2^{*}$ & 27.7 & $8.5 \pm 0.6$ & & 1.9 & \pm 3.2 \\
\hline & 3.0 & $2219 \pm 92 *$ & $10924 \pm 266^{*}$ & $30.0 \pm 5.6^{*}$ & $19.2 \pm 4.9 *$ & $7.3 \pm 0.3 *$ & $3.1 \pm 0.1 *$ & $10.7 \pm 0.8$ & $18.8 \pm 6.2$ \\
\hline \multirow[t]{3}{*}{ CM-R } & 0 & $0.9 \pm 0.2$ & $0.2 \pm 0.1$ & $109.0 \pm 10.3$ & $207.2 \pm 12.5$ & $5.8 \pm 0.1$ & $6.4 \pm 0.9$ & $19.2 \pm 0.6$ & $12.6 \pm 1.0$ \\
\hline & 1.5 & $833 \pm 37 *$ & $7022 \pm 13^{*}$ & $93.3 \pm 6.8^{*}$ & $71.1 \pm 2.7 *$ & $5.3 \pm 0.8$ & $5.0 \pm 0.4$ & $9.8 \pm 1.6^{*}$ & $10.5 \pm 1.2$ \\
\hline & 3.0 & $2274 \pm 138 *$ & $10552 \pm 157 *$ & $85.3 \pm 12.0^{*}$ & $53.8 \pm 4.2 *$ & $4.4 \pm 0.2 *$ & $4.1 \pm 0.8$ & $14.2 \pm 0.2 *$ & $11.8 \pm 2.0$ \\
\hline \multirow[t]{3}{*}{ CC-L } & 0 & $0.010-0.001$ & $0.024 \pm 0.001$ & $104.0 \pm 17.1$ & $59.1 \pm$ & $94.1 \pm 5.8$ & $71.7 \pm 7.6$ & $107.8 \pm 4.8$ & $75.0 \pm 5.3$ \\
\hline & 1.5 & $0.106 \pm 0.013^{*}$ & $0.358 \pm 0.012 *$ & $62.4 \pm 3.8^{*}$ & $44.8 \pm 2.5^{*}$ & $123.1 \pm 3.4 *$ & $176.8 \pm 1.6^{*}$ & $165.9 \pm 3.7 *$ & $101.2 \pm 6.9 *$ \\
\hline & 3.0 & $0.222 \pm 0.073^{*}$ & $0.567 \pm 0.067^{*}$ & $198.6 \pm 5.9^{*}$ & $104.8 \pm 2.3^{*}$ & $287.1 \pm 7.7^{*}$ & $144.4 \pm 1.1^{*}$ & $275.3 \pm 9.7^{*}$ & $122.2 \pm 9.0 *$ \\
\hline \multirow[t]{3}{*}{ CM-L } & 0 & $0.014 \pm 0.003$ & $0.027 \pm 0.006$ & $52.7 \pm 7.6$ & $88.6 \pm 1.4$ & $56.7 \pm 2.1$ & $44.3 \pm 10.5$ & $28.3 \pm 2.6$ & $51.3 \pm 6.1$ \\
\hline & 1.5 & $0.074 \pm 0.009 *$ & $0.103 \pm 0.003^{*}$ & $18.3 \pm 1.6^{*}$ & $16.1 \pm 1.1 *$ & $87.1 \pm 10.1^{*}$ & $389.1 \pm 70.7 *$ & $30.6 \pm 0.8$ & $99.9 \pm 4.2 *$ \\
\hline & 3.0 & $0.225 \pm 0.070^{*}$ & $0.193 \pm 0.008^{*}$ & $75.1 \pm 0.3 *$ & $54.6 \pm 0.6^{*}$ & $134.8 \pm 9.9 *$ & $915.8 \pm 13.1 *$ & $62.5 \pm 2.3^{*}$ & $91.9 \pm 9.1 *$ \\
\hline
\end{tabular}

Very similar pattern of hormone (JA, ABA and SA) changes in response to $\mathrm{Cd}$ were found in both genotypes independently of their different tolerance to this metal (Table 2). In roots, a decrease in JA content was observed in both genotypes and at both $\mathrm{Cd}$ concentrations while $\mathrm{ABA}$ and $\mathrm{SA}$ contents were less affected even if a decreasing pattern could be perceived. In leaves, a different picture was observed and ABA and SA contents increased in both genotypes in practically all data points but irregular variations in JA content were observed in response to increased $\mathrm{Cd}$ concentrations.

In the second experiment, plants of the two citrus genotypes were watered for $85 \mathrm{~d}$ with solutions containing $30 \mu \mathrm{M}$ or $150 \mu \mathrm{M} \mathrm{Cd} \mathrm{Cd}^{2+}$. Differences in $\mathrm{Cd}^{2+}$ uptake between $\mathrm{CC}$ and $\mathrm{CM}$ persisted under exposure to moderate Cd levels (data not shown). Interestingly, no visible symptoms of damage were observed throughout the studied period. In the same way, gas exchange parameters decreased less dramatically than in the previous experiment (data not shown). Neither roots nor leaves of citrus under these $\mathrm{Cd}^{2+}$ treatments showed clear hormonal variations.

From the data presented in this work, it seems clear that citrus genotypes are not $\mathrm{Cd}$ hyperaccumulators. Different parameters have been defined to include a species in this category (McGrath and Zhao 2003), including a shoot-to-root ratio of metal concentration greater than one (accounting for an efficient root-to-shoot transport), and a hypertolerance to metals inside cells. Data in Table 2 exclude citrus from this classification because $\mathrm{CC}$ and $\mathrm{CM}$ plants showed a high $\mathrm{Cd}$ retention capacity in the roots even when plants were watered with high doses of $\mathrm{Cd}^{2+}$, endogenous $\mathrm{Cd}$ content in leaves was below $0.6 \mu \mathrm{g} \mathrm{g}^{-1}$, being this level much lower than those reported in different tree species under $\mathrm{Cd}$ stress (Moreno-Jiménez et al. 2009). Our data are in agreement with previous reports indicating that roots of some woody species have a special capacity for retaining $\mathrm{Cd}$ (Unterbrunner et al. 2007, Brunner et al. 2008).
Despite the well-known sensitivity of citrus to high salinity in the watering solutions or drought (GómezCadenas et al. 1996, López-Climent et al. 2008), data presented in this work indicate that citrus plants tolerate $\mathrm{Cd}^{2+}$ to a certain extent. When watered with solutions containing 30 or $150 \mu \mathrm{M} \mathrm{Cd}^{2+}$, citrus did not show visible damage for more than two months. Interestingly, the extremely low $\mathrm{Cd}^{2+}$ concentrations found in leaves in comparison to the roots (Table 2) seem to support the hypothesis that most of the aerial damage observed (Table 1) is due to a root malfunctioning. A similar situation was observed in citrus plants under continuous soil flooding (Arbona and Gómez-Cadenas 2008).

The lower $\mathrm{Cd}$ translocation to the leaves found in $\mathrm{CM}$ than in CC could be related, at least in part, to the lower transpiration of this genotype (Table 1). It should be noted that recent research demonstrates that different processes are involved in the $\mathrm{Cd}$ transport from roots to shoots. These key processes would include immobilization inside the vacuoles of root cells, metal precipitation or binding of free metal cations to cell walls that can also slow down their movement into the shoot with the transpiration stream. Recently metal pumps responsible for the loading of zinc ions into the xylem have been proposed as essential in the accumulation of Cd into the shoot (Wong et al. 2009). In our system, all these factors are probably playing a key role in the translocation to the shoots but due to the high levels of $\mathrm{Cd}$ entering in the roots it could be also a plausible explanation that different transpiration rates have an influence in $\mathrm{Cd}$ translocation to the leaves. Other authors have linked transpiration to $\mathrm{Cd}$ buildup in aerial parts in different species (Salt et al. 1995, Van der Vliet et al. 2007). Even more, López-Climent et al. (2008) showed that in citrus chloride absorption and hence salt tolerance was linked to water use. In those studies, CM having a lower transpiration rate accumulated less chloride ions in leaves than $\mathrm{CC}$.

As raised by Clemens (2006), it is still a non- 
answered question whether plant responses are specific to $\mathrm{Cd}$ toxicity while this element apparently has no biological function. Citrus roots under different concentrations of $\mathrm{Cd}$, either did not respond or reduce ABA, SA and JA contents independently of the different tolerance to $\mathrm{Cd}$ observed in the two studied genotypes. This fact clearly indicates that there is no a specific hormonal response to the metal buildup in citrus genotypes. The so-called "stress hormones" did not clearly respond to this stimulus while it has been shown that the same genotypes are able to accumulate large amounts of phytohormones in roots under water stress (Gómez-Cadenas et al. 1996). The relative decreases in root JA and ABA levels had been previously observed (Arbona and Gómez-Cadenas 2008) in citrus under continuous flooding conditions and could reflect a

\section{References}

Arbona, V., Gómez-Cadenas, A.: Hormonal modulation of citrus responses to flooding. - J. Plant Growth Regul. 27: 241-250, 2008.

Ben Ammar, W., Mediouni, C., Tray, B., Ghorbel, M.H., Jemal, F.: Glutathione and phytochelatin contents in tomato plants exposed to cadmium. - Biol. Plant. 52: 314-320, 2008.

Brunner, I., Luster, J., Gunthardt-Goerg, M.S., Frey, B.: Heavy metal accumulation and phytostabilisation potential of tree fine roots in a contaminated soil. - Environ. Pollut. 152: 559-568, 2008.

Clemens, S.: Toxic metal accumulation, responses to exposure and mechanisms of tolerance in plants. - Biochimie 88: 1707-1719, 2006.

Di Toppi, L.S., Gabbrielli, R.: Response to cadmium in higher plants. - Environ. exp. Bot. 41: 105-130, 1999.

Gómez-Cadenas, A., Tadeo, F.R., Talon, M., Primo-Millo, E.: Leaf abscission induced by ethylene in water-stressed intact seedlings of Cleopatra mandarin requires previous abscisic acid accumulation in roots. - Plant Physiol. 112: 401-408, 1996.

Jiang, S., Liu, D.H., Xu, P.: Cd-induced system of defence in the garlic root meristematic cells. - Biol. Plant. 53: 369-372, 2009.

López-Climent, M.F., Arbona, V., Pérez-Clemente, R.M., Gómez-Cadenas, A.: Relationship between salt tolerance and photosynthetic machinery performance in citrus. Environ. exp. Bot. 62: 176-184, 2008.

Lugon-Moulin, N., Zhang, M., Gadani, F., Rossi, L., Koller, D., Krauss, M., Wagner, G.J.: Critical review of the science and options for reducing cadmium in tobacco (Nicotiana tabacum L.) and other plants. - Adv. Agron. 83: 111-180, 2004.

Markovska, Y.K., Gorinova, N.I., Nedkovska, M.P., Miteva, K.M.: Cadmium-induced oxidative damage and antioxidant responses in Brassica juncea plants. - Biol. Plant. 53: 151154, 2009.

McGrath, S.P., Zhao, F.J.: Phytoextraction of metals and metalloids from contaminated soils. - Curr. Opin. Biotechnol. 14: 277-282, 2003.

Moreno-Jiménez, E., Peñalosa, J.M., Manzano, R., CarpenaRuiz, R.O., Gamarra, R., Esteban, E.: Heavy metals distribution in soils surrounding an abandoned mine in NW progressive decay of root activity. Contrastingly, those plants under high toxic conditions showed progressive increases in leaf concentration of the stress hormones. These signaling events must be an indirect effect derived from a root malfunctioning (Xu et al. 2009) and therefore a general response to stress. Due to the extraordinarily low accumulation of $\mathrm{Cd}$ in leaves (in comparison with roots), it seems unlikely that the observed accumulation of hormones could be a specific response to the metal. Moreover, no important variations in hormonal profiles in leaves of the same plants were observed when Cd excess was not toxic for plants. All these data together seem to discard that endogenous JA, ABA or SA may function in citrus as specific signaling molecules that sense $\mathrm{Cd}$ toxicity.

Madrid (Spain) and their transference to wild flora. - J. Hazard Mater. 162: 854-859, 2009.

Rascio, N., Vecchia, F.D., La Rocca, N., Barbato, R., Pagliano, C., Raviolo, M., Gonnelli, C., Gabbrielli, R.: Metal accumulation and damage in rice (cv. Vialone nano) seedlings exposed to cadmium. - Environ. exp. Bot. 62: 267-278, 2008.

Rodriguez-Serrano, M., Romero-Puertas, M.C., Pazmino, D.M., Testillano, P.S., Risueno, M.C., Del Rio, L.A., Sandalio, L.M.: Cellular response of pea plants to cadmium toxicity: cross talk between reactive oxygen species, nitric oxide, and calcium. - Plant Physiol. 150: 229-243, 2009.

Salt, D.E., Prince, R.C., Pickering, I.J., Raskin, I.: Mechanisms of cadmium mobility and accumulation in Indian mustard. Plant Physiol. 109: 1427-1433, 1995.

Schat, H., Sharma, S.S., Vooijs, R.: Heavy metal-induced accumulation of free proline in a metal-tolerant and a nontolerant ecotype of Silene vulgaris. - Physiol. Plant. 101: 477-482, 1997.

Schutzendubel, A., Schwanz, P., Teichmann, T., Gross, K., Langenfeld-Heyser, R., Godbold, D.L., Polle, A.: Cadmium-induced changes in antioxidative systems, hydrogen peroxide content, and differentiation in Scots pine roots. - Plant Physiol. 127: 887-898, 2001.

Unterbrunner, R., Puschenreiter, M., Sommer, P., Wieshammer, G., Tlustos, P., Zupan, M., Wenzel, W.W.: Heavy metal accumulation in trees growing on contaminated sites in Central Europe. - Environ. Pollut. 148: 107-114, 2007.

Van der Vliet, L., Peterson, C., Hale, B.: Cadmium accumulation in roots and shoots of durum wheat: the roles of transpiration rate and apoplastic bypass. - J. exp. Bot. 58: 2939-2947, 2007.

Wagner, G.J.: Accumulation of cadmium in crop plants and its consequences to human health. - Adv. Agron. 51: 173-212, 1993.

Wong, C.K.E., Jarvis, R.S., Sherson, S.M., Cobbett, C.S.: Functional analysis of the heavy metal binding domains of the $\mathrm{Zn} / \mathrm{Cd}$-transporting ATPase, HMA2, in Arabidopsis thaliana. - New Phytol. 181: 79-88, 2009.

Xu, P., Liu, D., Jiang, W.: Cadmium effects on the organization of microtubular cytoskeleton in interphase and mitotic cells of Allium sativum. - Biol Plant. 53: 387-390, 2009. 